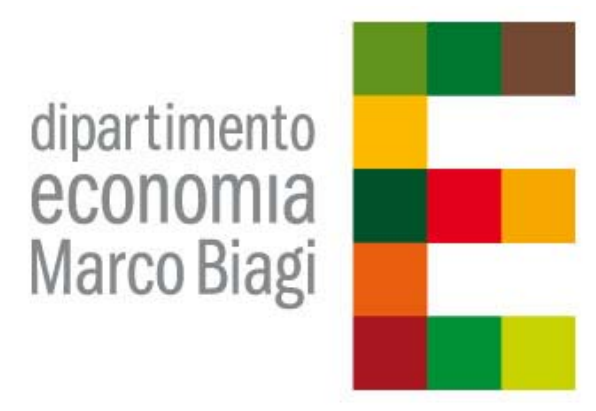

DEMB Working Paper Series

N. 32

\title{
Capital Inflows, Current Accounts and Investment Cycle in Italy: 1861-1913
}

\author{
Barbara Pistoresi* \\ Alberto Rinaldi ${ }^{* *}$
}

April 2014

\begin{abstract}
Affiliations and addresses of the authors:
Dipartimento di Economia Marco Biagi and ReCent, Università di Modena e Reggio Emilia, Viale Berengario 51, 41100 Modena Italy

email: barbara.pistoresi@unimore.it

Corresponding author:

Dipartimento di Economia Marco Biagi

Università di Modena e Reggio Emilia, Viale Berengario 51, 41100 Modena Italy

email: alberto.rinaldi@unimore.it
\end{abstract}

ISSN: 2281-440X online 
Barbara Pistoresi and Alberto Rinaldi

CAPITAL INFLOWS, CURRENT ACCOUNTS AND INVESTMENT CYCLE IN ITALY: 1861-1913

\begin{abstract}
:
By relying on a new dataset, this paper presents an econometric strategy to test the Fenoaltea's thesis with regard to both the genesis of current account fluctuations and of the investment cycle. We perform a Granger causality test that shows that the persistent current account deficits in the years from unification from WW1 were generated by variations in capital inflows, as pointed by Fenoaltea, and not by the dynamics of the GDP, as claimed by the Bonelli-Cafagna model. Finally, this paper supports the Fenoaltea's thesis that these capital inflows prompted a general investment cycle which included both construction and industrial investments.
\end{abstract}

JEL Code: F43; O11; N1; N7

Keywords: Capital imports, current accounts, investment cycle, Italy, integration, cointegration and Granger causation analysis 


\section{Introduction}

The dynamics of Italy's balance of payments (BOP) in the years of the "classical" gold standard has been widely debated. Until the 1980s, the prevailing view was broadly Keynesian (Bonelli 1978; Cafagna 1989). It was assumed that exports were totally exogenous, determined by core country demand for the nation's products, while imports are a function of the nation's GDP. In this scenario, the trade balance - and, more generally, the current account (CA) balance - is seen as highly sensitive to the domestic rate of growth; if the rate exceeds some threshold level, the balance would be plunged into deficit. In the short run, this deficit can be financed by selling reserves or by importing capital, while in the medium run, devaluation can provide some relief. However, devaluation is at best a stop-gap measure, since prices are inelastic. In the long run, the only effective solution to CA problems is a lower growth rate.

After political unification in 1861, Italy was a relatively backward and resource-poor country, which required massive investment in plant, equipment and modern infrastructure to prompt industrialization. Since the import content of domestic output growth was large, the problem was to find the way to ease CA pressures. According to this view, a long wave of growth began in the late $18^{\text {th }}$ century - well before Italy's political unification - stimulated by an expansion of agricultural exports, particularly raw silk. The upswing also permitted imports of raw materials and semimanufactured goods to increase without putting pressure on the CA. The agrarian crisis of the 1880s put an end to the leading role of agriculture as Italy's export engine but, by that time, other sectors (especially textiles and other manufactures) had taken up the slack and a mix of emigrant remittances and tourism helped to finance growth-induced imports.

In recent years, the Cafagna-Bonelli view has been turned upside-down. It is now assumed that the driving force was capital flows, and that the balance of trade and the CA balance adjusted to them. When capital flowed in, for whatever reason, the CA balance was in deficit; when Italy exported capital, the CA balance was in surplus. Two hypothesis have been put forward about what drove capital flows. Fratianni and Spinelli (1984) and, more explicitly, Spinelli (1988) focus on the difference between actual and desired money supply in the framework of the monetary theory of BOP. Italy exported capital (and the lira depreciated) when the money supply (driven up by state deficit) exceeded the desired one, thereby forcing the nation to abandon the parity with gold, as it was the case from 1866 to 1882 . Instead, Fenoaltea $(1988,2011)$ stresses the role of the decisions by core countries' investors - especially Britons - about the profitability and risks of domestic and foreign investment. When, as in the 1880 s, they preferred investing abroad, the world capital market 
was flooded with liquidity, and all peripheral countries - including Italy - imported huge quantities of capital.

As it is well-known, capital inflows and the CA deficit move together. In general, either may cause the other. The CA balance is the theoretical variable in Fenoaltea's argument. However, as the movement of goods is the least uncertain component of Italy's BOP, this author in his empirical investigation uses the trade balance as a proxy for the CA balance. Fenoaltea (2011) observed that a BOP equilibrium can be disturbed by impulses that arise in the market for goods, or in the market for capital. In the former case, if a trade deficit appears because of an increase in imports, it tends to reduce the real exchange rate (either through a devaluation of the currency, with flexible exchange rates, or through a reduction of the internal price level, relative to the foreign one, with fixed exchange rates). The trade deficit is covered by induced capital inflows: with flexible exchange rates the devaluation of the currency may be seen as temporary, causing speculative purchases of the nation's currency in view of its subsequent recovery; with fixed exchange rates the loss of currency causes a net demand for liquidity that attracts foreign loans. In the event, the trade deficit and capital imports increase together, accompanied by a decline in the real exchange rate. If the initial equilibrium is disturbed in the opposite sense, by an increase in exports, the trade deficit and capital imports decline together, while the real exchange rate increases. In the alternative scenario, a BOP disequilibrium appears because the nation imports more capital than before. As a result, the real exchange rate rises (as the currency appreciates, or the domestic price level increases relative to the foreign one). This rise in the real exchange rate in turn increases the trade deficit: the trade deficit and capital imports again rise together, and the real exchange rate rises too. If the initial equilibrium is disturbed in the opposite sense, by a reduction in capital imports, the trade deficit and capital imports decline together, and the real exchange rate also declines. The trade deficit and capital imports move together in any case: but with parallel movements in the real exchange rate if the initial impulse is in financial markets and the capital flows cause the trade deficits, and with opposite movements in the real exchange rates if the initial impulse is in the goods market and the trade deficits cause the flows of capital. Fenoaltea showed that, prior to WW1, the Italian currency was strong when the trade deficits and capital flows were high, and weak when they were low. With a brief exception in the early 1870 s, the movement in the real exchange rate was parallel to that in the trade deficit and capital imports: the trade-deficit cycle was generated by the capital-import cycle, and not vice-versa.

In Fenoaltea's analysis capital flows are not only the determinant of BOP fluctuations, but also the main cause of business cycles in Italy. In an attempt to explain Italy's economic growth and fluctuations, Fenoaltea (1988) argued that swings in Italian construction and in other activities were 
strictly supply-induced, driven by fluctuations in British capital exports that were, in turn, determined by investor sentiment in Britain. Capital inflows in Italy were due to an abundance of foreign supply, and not to the pressure of investment demand exceeding domestic saving: capital inflows were the cause, and not the effect, of the construction cycle. In a more recent formulation, Fenoaltea (2011) held that exogenous capital inflows prompted not just the construction cycle, but a more general investment cycle in Italy. Construction and industrial investment were part of the same cycle: both were high when capital inflows were abundant and were low when foreign capital withdrew from the country. Thus, he maintained that Italy's investment cycle was no more than the Italian component of a world-wide cycle in capital formation common to the financial periphery as a whole. The willingness of non-Italians to invest in Italy rose and fell with their willingness to invest in foreign assets in general and, contrary to what was argued by other authors - i.e., Warglien (1987) and, more recently, Bolchini (2006), Ciocca (2006) and De Cecco (2006) ${ }^{1}$ - only marginally influenced by the fluctuations in the supply of domestic capital. This means that the Italian cycle in capital formation (and, derivatively, in industrial and total production) was set in motion not by domestic economic and political factors but by external, globe-spanning events over which Italian governments had no or very little control.

By relying on a new dataset, this paper presents an econometric strategy to test the Fenoaltea's thesis with regard to both the genesis of the CA fluctuations and of the investment cycle. Using integration, cointegration and Granger causation analysis we find the following results. Italy's CA to GDP series is not stationary over the 1861-1913 years, due to persistent deficits in the $1860 \mathrm{~s}$, in the 1880 s and in the five years prior to WW1. By analysing the genesis of CA fluctuations we find that these were generated by variations in capital inflows, as in Fenoaltea, and not by the dynamics of the GDP, as in the Bonelli-Cafagna view. Lastly, we find that these CA deficits triggered a general investment cycle which included both construction and industrial investments.

This paper is structured as follows. After this Introduction, section 2 presents the sources and data we have used in our analysis. Section 3 illustrates the evolution of Italy's BOP and real investment series from Unification in 1861 to 1913. Section 4 presents an econometric strategy to test Fenoaltea's thesis according to which in the years 1861-1913. Lastly, Section 5 concludes.

${ }^{1}$ These latter contributions are published in Bolchini et al. (2006). 


\section{Sources and data}

In 1957 the Italian national statistical office produced the first estimate of Italy's BOP for the period 1861-1956 (Istat 1957). However, several objections were raised against these series, which proved unreliable and internally inconsistent. In particular, as far as the years prior to WW1 are concerned, Istat seems to have significantly overestimated the earnings of services, and especially of tourism (Marolla and Roccas 1992; Zamagni 1992). But, above all, Istat emigrants' remittances seem excessively variable. In fact, these estimates appear to be based on the gross flow of migrants, which similarly jumps up in 1901 and 1905, whereas remittances seem more reasonably tied to the savings by the stock of Italians abroad, which grew more smoothly from under one million in 1871 to some six million in 1911 (Fenoaltea 2011).

To tackle such criticism, Morys (2006) presented a new and more reliable series of Italy's BOP for the period 1868-1913. The major difference with regard to the Istat series concerns the criteria that have been used to estimate emigrants' remittances. In the absence of good data relating to the money transferred by Italian emigrants, Morys relied on the number of emigrants and approximated what an average Italian emigrant would transfer home in his first, second, third etc. years based on some general rules on what determines the pattern of remittances that have been discussed in the international literature on emigration. As this author reconstructed also the remittances for AustriaHungary - for which much better data are available - he could double-check his results and found that the series for this latter country was very close to the one he constructed by using the general rules presented in the literature.

As to the GDP series, Istat (1957) presented an estimates of Italy's national accounts for the 18611956 years which included a detailed reconstruction of both production side and expenditure side at current prices, and of the latter alone at constant (1938) prices; 1938-price product series were also provided for core agriculture (cultivation and herding) and for manufacturing industry. However, this work lacked key series (such as output by sector at constant prices), details on methodology and sources, and an appropriate degree of skepticism about official statistical sources (Cohen and Federico 2001). These series were only partially improved by a team of scholars led by the economist Giorgio Fuà, which provided new estimates of value added by sector at constant (1938) prices, implicit deflators by sector and use, and a comprehensive series on the capital stock from 1881 onwards (Ercolani, 1969; Fuà, 1965, 1969; Vitali, 1969). Yet, the Fuà team did not attempt to rebuild the core of the work by Istat: the estimates of value added at current prices. For this reason many scholars, troubled by flaws in the original data, remained unconvinced by this revision (Cohen and Federico 2001). 
It was only on occasion of the $150^{\text {th }}$ anniversary of Italy's unification, celebrated in 2011 , that a project coordinated by the Bank of Italy presented a reconstruction of the national accounts, complete in both the production and expenditure sides, for the whole century and a half since unification (Baffigi 2011; Brunetti, Felice and Vecchi 2011).

In this paper, we test the Fenoaltea's argument by using a new dataset which, for the CA, uses the Istat (1957) series for the years 1861-1867 and the Morys (2006) series for the years 1868-1913. As to GDP, total investments; investment in constructions; and investments in plant, machinery, and transport equipment it relies on the new series that have been provided by the Bank of Italy for the $150^{\text {th }}$ anniversary of the nation's political unification (Baffigi 2011). Lastly, the series of Italy's real exchange is drawn from Fenoaltea (2011). ${ }^{2}$

\section{The evolution of Italy's current accounts}

Figure 1 shows the evolution of Italy's BOP from 1861 to 1913. The dynamics of the CA to GDP and of the trade balance to GDP ratios are distinctly reported. The trade balance was negative throughout the period under investigation. This persistent deficit was at least partially covered by other headings of the CA balance, above all remittances of Italian emigrants abroad and tourism. As a result, the CA balance performed far better and was positive in 21 years out of 54 . A persistent CA surplus was obtained for eighteen years in a row from 1891 to 1908 . However, there were also three periods of persistent CA deficits: $1861-70,1879-90$, and 1909-13. ${ }^{3}$

\footnotetext{
${ }^{2}$ Italy followed a bimetallic standard from 1861 to 1866 , when convertibility was suspended in the wake of war against Austria. Italy re-enacted gold convertibility in 1883, but was forced to suspend specie payment again in 1893 . Mint parity was achieved again in 1903 and maintained until the outbreak of WW1, but convertibility of bank notes into specie was not introduced. In sum, Italy was the jure on gold from 1883 to 1893 and de facto on gold from 1903 to 1914 (Morys 2006). The nominal exchange rate of the lira was therefore semi-flexible, in the sense that it could fall below the metal parity of the currency unit but not rise above it. With the nominal exchange rate at par, the real exchange rate rises with an increase in the domestic price level, relative to that abroad (world-wide, commodity prices fell from the early 1870 s to the mid-1890s, and then rose steadily). But the domestic prices of imported goods remain tied to their foreign prices, converted into lire at a constant exchange rate; the relative increase in the domestic price level is due entirely to the increase in the price of the goods least subject to import competition, real estate and services first and foremost. Thus, Fenoaltea (2011: Table 2.05) calculated the real rent index and used it as a proxy of real exchange. We also use it in our dataset.

${ }^{3}$ By contrast, Spain showed persistent CA deficits from 1850 to 1890 . These were followed by a period, between 1891 and 1913, in which surpluses prevailed, with the exception of the years 1899-1904 (Prados de la Escosura 2010).
} 
Fig. 1 - CA/GDP and TB/GDP ratios in Italy (1861-2000)

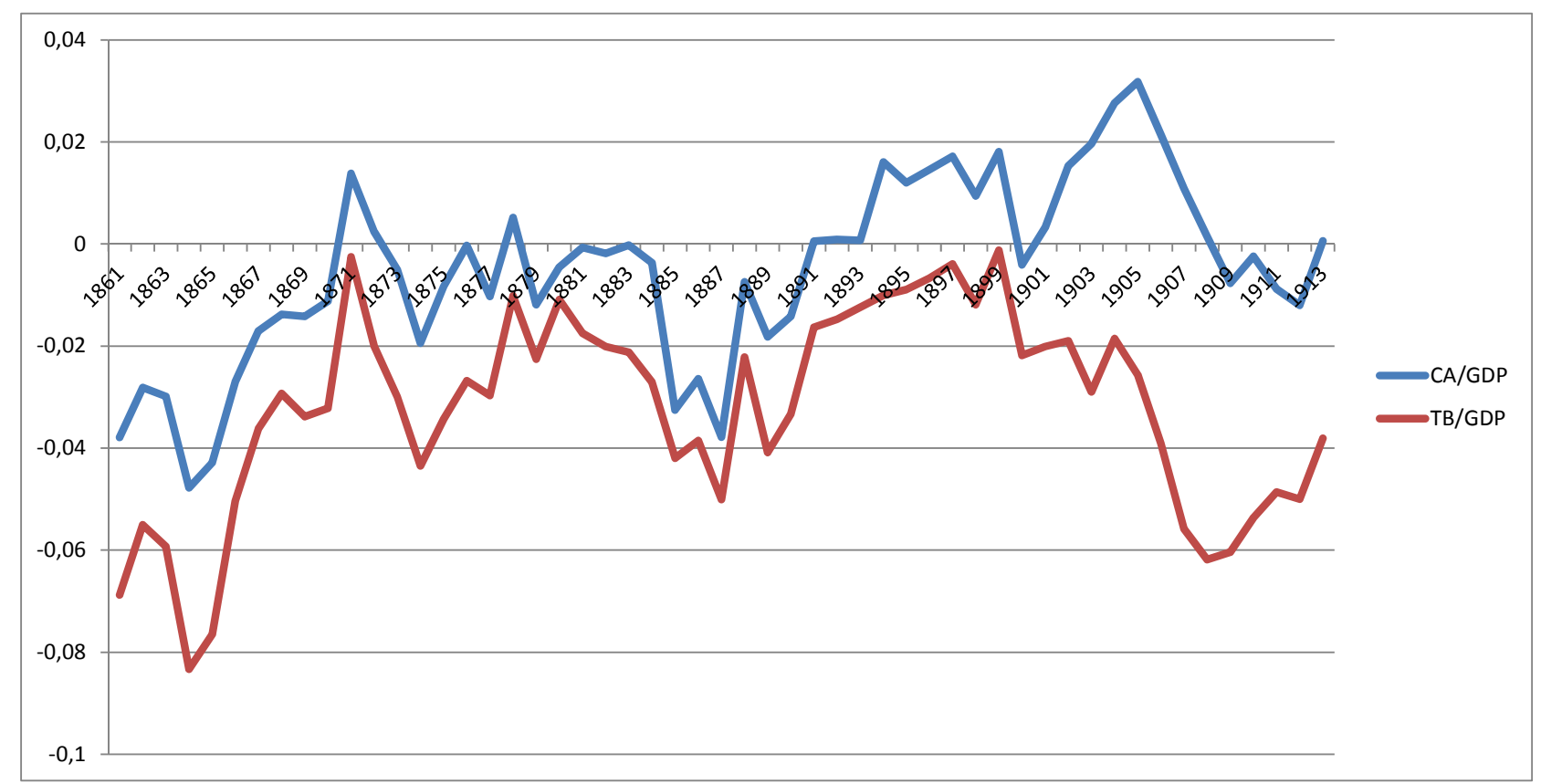

Legend: $\mathrm{CA} / \mathrm{GDP}=$ Current Account to GDP ratio; TB/GDP = Trade Balance to GDP ratio.

Figure 2 shows the dynamics of real investments in Italy: the series of investments in constructions; in plant, machinery and transport equipment; and total investments are distinctly reported.

Total investments grew from 1861 to 1865 , but then they declined for e few years in the wake of the war against Austria. They doubled from 1871 to 1874 (the so-called "feverish triennium"); after ups and downs they dropped back in the late 1870s. The 1880s saw another upswing, which was followed by a fall in the following decade. Investment began to accelerate sharply at the end of the $19^{\text {th }}$ century until 1907. This was the year of world crisis, when Italy's accumulation activity reached a peak which was followed by another fall in the five years leading to WW1.

In brief, in the years from Unification to WW1 the Italian economy went through a number of investment cycles that were characterized by phases of rapid growth followed by sharp downward swings. Fluctuations over time were sharper in industrial investments (plant, machinery and transport equipment) than in construction. Industrial investments also exhibited a higher growth trend: in 1861 investments in constructions were three times as high as those in plant, machinery and transport equipment, whereas in 1907, at the peak of the Italian pre-WW1 investment cycle, the latter were three times as high as the former. The higher dynamics of industrial investment, as compared to investment in other sectors, triggered structural change in the Italian economy and 
facilitated a shift of productive factors from low to high productivity activities, especially from agriculture and constructions to manufactures.

Another point to be emphasized is that upswings in the investment cycle occurred at a time when the CA balance was in deficit or showed a sharp decrease of its surpluses. The only exception is represented by the years from 1901 to 1905, which were characterized by both a boom in investment activity and growing CA surpluses, which were due to the increasing revenues from emigrants remittances. However, the 1907 peak in the investment cycle was preceded by a sharp decline in the CA surpluses in 1905 and 1906.

Fig. 2 - Real investments in Italy (1861-1913)*

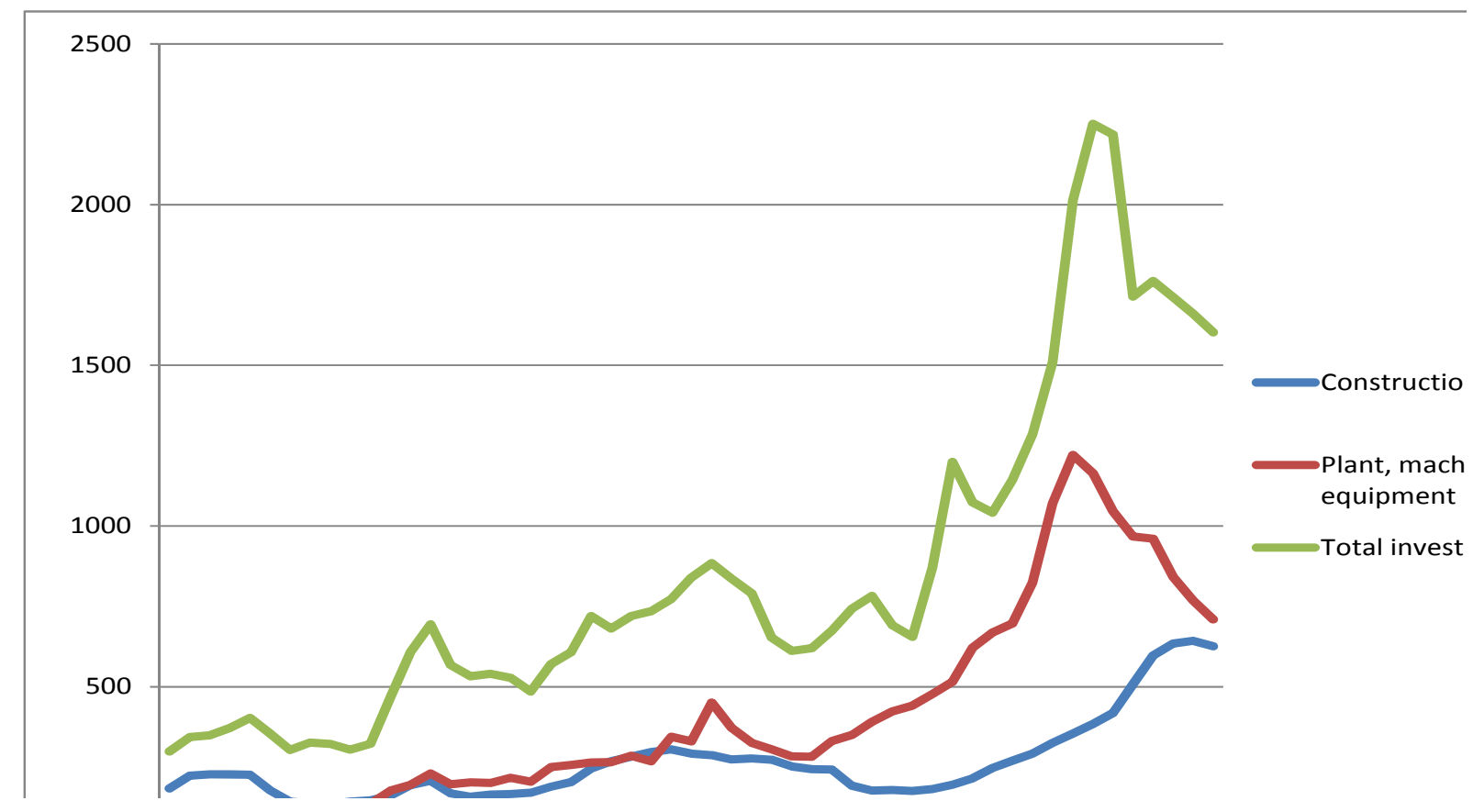

* Values in thousands euros, 1911 prices

\section{Testing the Fenoaltea's thesis: an econometric strategy}

Persistent external deficits can constrain economic growth because they can increase the interest rates the nation has to pay to attract foreign capital, and impose an excessive burden on future generations increasing interest payments and lowering the standard of living. This is the thesis underlying the Bonelli-Cafagna view. However, there are also cases in which persistent CA deficits 
are not linked to severe domestic macroeconomic imbalances and hence they do not curb economic development. As anticipated in the Introduction, Fenoaltea (2011) suggests that Italy's external deficits in the years 1860-1913 were determined by capital inflows, that boosted the investment cycle, i.e., they were used to finance investments in constructions and the imports of machinery, technology, raw materials, and other capital goods, which in turn prompted economic growth.

Hence, a BOP disequilibrium appears because the nation imports more capital than before. As a result, the real exchange rate rises (as the currency appreciates, or the domestic price level increases relative to the foreign one). This surge in the real exchange rate in turn increases the trade deficit and the CA deficit (as the trade balance is by far the main component of the CA balance): the trade deficit and capital imports rise together, and the real exchange rate rises too. A similar argument holds if the initial equilibrium is disturbed in the opposite sense, by a reduction in capital imports: the trade deficit and capital imports decline together, and the real exchange rate also declines.

Fenoaltea shows that, prior to WW1, the Italian currency was strong when the trade deficits and capital flows were high, and weak when they were low. With a brief exception in the early 1870 s, the movement in the real exchange rate was parallel to that in the trade deficit and capital imports: the trade-deficit cycle was generated by the capital-import cycle, and not vice-versa.

The increasing integration of capital markets in the years of the "classical" gold standard led Italy to participate fully in the financial relations between the core and the periphery of the world economy. The world cycle in capital flows stemmed from the long swing in the confidence of core countries' investors - especially British savers - in the investment in the periphery. Data on the premium required to invest in Italian bonds show that it followed a pattern similar to that of the entire periphery. Thus, the Italian investment cycle seems to have been no more than the Italian component of a world-wide investment cycle: the willingness of non-Italians to invest in Italy rose and fell with their willingness to invest in the periphery as a whole, without significant peculiarities tied to Italy itself.

The Fenoaltea's argument can be represented by this sequence of causation (henceforth, Fenoaltea's cycle):

$\uparrow \downarrow$ Foreign capital inflows $\rightarrow \uparrow \downarrow$ real exchange rate $\rightarrow \uparrow \downarrow$ trade deficits $\rightarrow \uparrow \downarrow$ CA deficits $\rightarrow \uparrow \downarrow$ real investment 
This nexus among the changes in real exchange rate, CA balance and real investment can be analysed in an econometric framework by using techniques appropriate for estimating long run equilibrium and testing causation. In the case of time series data a test for the direction of causation is suggested by Granger (1969). For simplicity, Equations (1) to (4) present the testing strategy for the bivariate case. A variable $\mathrm{X}$ improves the prediction of a variable $\mathrm{Y}$, that is $\mathrm{X}$ Granger causes $\mathrm{Y}$, if current $\mathrm{Y}$ can be predicted better by using past values of $\mathrm{X}$ than by not doing so, given that all other past information in the information set is used. Suppose $\mathrm{X}$ and $\mathrm{Y}$ are linear covariance stationary time series. ${ }^{4}$ Thus $\mathrm{X}$ and $\mathrm{Y}$ can be written as follows:

(1) $X_{t}=\sum_{i=1}^{m} a_{i} X_{t-i}+\sum_{j=1}^{n} b_{j} Y_{t-j}+\varepsilon_{t}$

(2) $Y_{t}=\sum_{i=1}^{m} c_{i} Y_{t-i}+\sum_{j=1}^{n} d_{j} X_{t-j}+u_{t}$

where $\varepsilon_{t}, u_{t}$ are zero mean and finite covariance matrix random vector. The causality test is

a) $\mathrm{X}$ causes $\mathrm{Y}$ if $H_{0}: d_{j}=0, j=1, \ldots, n$ is rejected

b) Y causes $\mathrm{X}$ if $H_{0}: b_{j}=0, j=1, \ldots, n$ is rejected

Bidirectional causality occurs if both (a) and (b) hold. Unidirectional causality from X to Y occurs if (a) holds but (b) does not. In order to test these null hypothesis in (a) and (b), F statistics are calculated for jointly significance of the $d_{j}$ in equation (1) and for $b_{j}$ in equation (2).

For the Granger causation test, the hypothesis of covariance stationarity of the time series used is crucial to avoid spurious results. In general, the levels of the time series are not covariance stationary while their first difference are stationary. The first difference of these variables $(\Delta X$ and $\Delta Y)$ are stationary, while $\mathrm{X}$ and $\mathrm{Y}$ are not. If these are the statistical properties of the variables, we can only test for Granger causation by using first difference stationary models, that is

\footnotetext{
${ }^{4}$ Time series are said to be covariance stationary if their moments up to the second order do not depend on time. Hence, for instance the mean must be constant and the shocks affecting stationary series have only temporary effects. These time series are also said I(0). By contrast a series is said to be difference stationary if its first difference is stationary but the series itself is not. A property of difference stationary series is that they do not have necessarily constant means and the variance grows with time without limit, moreover the shocks affecting them are permanent. These series are also said $\mathrm{I}(1)$.
} 
(3) $\Delta X_{t}=\sum_{i=1}^{m} a_{i} \Delta X_{t-i}+\sum_{j=1}^{n} b_{j} \Delta Y_{t-j}+\varepsilon_{t}$

(4) $\Delta Y_{t}=\sum_{i=1}^{m} c_{i} \Delta Y_{t-i}+\sum_{j=1}^{n} d_{j} \Delta X_{t-j}+u_{t}$

However, the nexus among real exchange rate, CA deficit (or surplus) and real investment may be a long run relationship. If this long run nexus exists but we do not include it in the estimation of models (3) and (4) we have mis-specification and "spurious causality". Hence, we have to test for Granger causation, to take into account the possible long run relationship among the levels (values) of real exchange rate, $\mathrm{CA}$, and real investment among their short run dynamics. Granger type causality tests for a long run relationship are valid if the relevant variables are found to be cointegrated, that is they move together so closely over the long run that they share a stochastic (and possibly also deterministic) trend in common. In this latter case, as stressed by Granger (1988), there is a presumption for causality to run in at least one direction.

Suppose $\mathrm{X}$ is the $\mathrm{CA}$ to GDP ratio, $\mathrm{Z}$ the real exchange rate and $\mathrm{Y}$ is the real investment. Moreover suppose these series are not covariance stationary, but they are cointegrated co-moving over time. In this case a three variables generalization of the Granger causality test, as in point (a) and (b) stated before, must be performed on the following ECM models:

$$
\begin{aligned}
& \Delta X_{t}=\sum_{i=1}^{m} a_{i} \Delta X_{t-i}+\sum_{j=1}^{n} b_{j} \Delta Y_{t-j}+\sum_{k=1}^{K} e_{k} \Delta Z_{t-k}+\delta E C T_{t-1}+\varepsilon_{t} \\
& \Delta Y_{t}=\sum_{i=1}^{m} c_{i} \Delta Y_{t-i}+\sum_{j=1}^{n} d_{j} \Delta X_{t-j}+\sum_{k=1}^{K} f_{k} \Delta Z_{t-k}+\delta E C T_{t-1}+\varepsilon_{t} \\
& \Delta Z_{t}=\sum_{i=1}^{m} g_{i} \Delta Z_{t-i}+\sum_{j=1}^{n} h_{j} \Delta Y_{t-j}+\sum_{k=1}^{K} l_{k} \Delta X_{t-k}+\lambda E C T_{t-1}+\eta_{t}
\end{aligned}
$$

where ECT is the error correction term derived by cointegration analysis representing the long run equilibrium among the variables.

Suppose that the cointegration does not exists among these variables the ECM models above collapse in these short run specifications (ADL models)

$$
\Delta \boldsymbol{X}_{t}=\sum_{i=1}^{m} \boldsymbol{a}_{i} \Delta \boldsymbol{X}_{t-i}+\sum_{j=1}^{n} \boldsymbol{b}_{j} \Delta \boldsymbol{Y}_{t-j}+\sum_{k=1}^{K} \boldsymbol{e}_{k} \Delta \boldsymbol{Z}_{t-k}+\varepsilon_{t}
$$




$$
\begin{aligned}
\Delta \boldsymbol{Y}_{t} & =\sum_{i=1}^{m} \boldsymbol{c}_{i} \Delta \boldsymbol{Y}_{t-i}+\sum_{j=1}^{n} \boldsymbol{d}_{j} \Delta \boldsymbol{X}_{t-j}+\sum_{k=1}^{K} \boldsymbol{f}_{\boldsymbol{k}} \Delta \boldsymbol{Z}_{\boldsymbol{t}-\boldsymbol{k}}+\varepsilon_{t} \\
\Delta \boldsymbol{Z}_{\boldsymbol{t}} & =\sum_{i=1}^{m} \boldsymbol{g}_{i} \Delta \boldsymbol{Z}_{t-i}+\sum_{j=1}^{n} \boldsymbol{h}_{j} \Delta \boldsymbol{Y}_{t-j}+\sum_{k=1}^{K} \boldsymbol{I}_{\boldsymbol{k}} \Delta \boldsymbol{X}_{t-\boldsymbol{k}}+\eta_{t}
\end{aligned}
$$

The Fenoaltea's thesis states that the real exchange rate dynamics is exogenous with respect to CA and investment variables, that is it only depends on its past values. This implies $\boldsymbol{h}_{\boldsymbol{j}}=\boldsymbol{I}_{\boldsymbol{k}}=0$ in model (10). CA variations are Granger caused by real exchange rate dynamics and hence $\boldsymbol{b}_{\boldsymbol{j}}=0$ in model (8), while the dynamics of real investment is Granger caused by the CA fluctuations. This latter implies that in model (9) possibly $\boldsymbol{f}_{\boldsymbol{j}}=0$.

The existence of this time lags structure in the above models is justified as follows:

a) It takes time for a change in real exchange rate to affect import and export spending, so the change in current account lags the change in real exchange rate;

b) It takes even more time to install capital equipment, so that investment can lag the real exchange rate and the current account variations.

This time lag structure makes sense since Fenoaltea (2011) stresses that in post-Unification Italy real the exchange rate was flexible. If for more than a half of the years from 1861 to 1913 the nominal exchange rate was fixed to mint parity, both prices and wages were flexible thereby getting the real exchange rate adjusted by movements in the relative price levels. When, from 1866 to 1882 and again from 1893 to 1903, the convertibility of the Italian lira was suspended, the real exchange rate was doubly flexible as its adjustment was pushed by movements in both nominal exchange rate and the relative price levels.

To sum up, the causality testing procedure involves three steps. The first step is to test whether our variables of interests are stationary or not (integration analysis). If they are not stationary, the second step is to test for cointegration, that is for the existence of long run relationships among them. If cointegration exists, Granger causality must be tested on the ECM models 5-7, if cointegration does not exist, on models 8-10.

Hence, in the following we present the results of the univariate integration analysis on the series. ${ }^{5}$ In particular, Table 1 summarizes the final outcomes for ADF (OLS/GLS) and KPSS tests for the

\footnotetext{
${ }^{5}$ We perform ADF tests (OLS/GLS) and KPSS test. The null of the ADF tests is non stationary series (unit root) while the null of the KPSS is stationary series. Hence, if both reject their nulls then we have no confirmation, but if test ADF rejects the null but test KPSS does not (or viceversa) we have confirmation. See Dickey and Fuller (1979) and
} 
levels and first differences of the variables involved in the Fenoaltea's cycle by using different specifications and lags. All the variables in levels are non stationary, in particular I(1), so we need to use in our analysis their first differences.

Table 2 shows that there is no cointegration between the variables involved in the Fenoaltea's cycle: the relationships among real exchange rate, CA to GDP ratio, and different real investment series have a short-medium term nature, that is these variables do not share common trends in the long run. ${ }^{6}$ This result implies that we have to use the ADL models 8-10. Tables 3 to 5 presents the results of Granger causality for different ADL models (different lags). From all the specifications in all the Tables the exogeneity of the real exchange rate strongly emerges: changes in the CA to GDP ratio and in investment do not cause variations in the real exchange rate. That is, in the years 1861-1913 real exchange rate movements seem to be due to external shocks, i.e. in foreign capital inflows as suggested by Fenoaltea.

Moreover, Tables 3 to 5 present the Granger causation analysis including the variations in real investment to close the Fenoaltea's cycle. In particular, Table 3 considers the real investment in plant, machinery and transport equipment; Tables 4 the real investment in constructions, and Table 5 the real total investment. All the ADL specifications (for different lags) presented in these Tables support Fenoaltea's argument. We find unidirectional Granger causation from real exchange rate to the CA to GDP ratio: Italy's persistent external deficits in the years 1861-1913 were determined by capital inflows and not by impulses that rose in the market for goods. We also find unidirectional Granger causation from the CA to GDP ratio to all the real investment series we consider. That is, it seems that CA deficits were used to trigger a general investment cycle which included both construction and industrial investment.

Unfortunately, data that disaggregate capital inflows between FDI and portfolio investments are not available for pre-WW1 Italy.

Nonetheless, it is well-known that, starting from the $1880 \mathrm{~s}$, foreign capital flew to Italy to boost investments in transport (railways and tramways) and utilities (gas, light and water supply) which sustained a progressive process of urbanization in the largest centers of the peninsula, as Milan, Genoa, Turin, and Naples. At the same time, foreign entrepreneurs started successful ventures capital- and technology- intensive industries, such as electricity and electro-mechanics, but also in cotton (Zamagni 1978).

Kwiatkowski et al. (1992). For a detailed analysis of the results of the integration analysis by using ADF (GLS) and KPSS see Pistoresi and Rinaldi (2013).

${ }^{6}$ The no cointegration result is also obtained with DOLS and Johansen cointegration procedure. For DOLS see Stock and Watson (1993) while for Johansen procedure see Johansen (1991). 
On the eve on WW1, there were several industries in Italy that were characterized by a substantial presence of foreign capital. In the energy industry (basically, electricity), FDI accounted for nearly 50 per cent of the total capital invested in that sector. Moreover, foreign-owned firms controlled 13 per cent of share capital in the textile industry, 43 per cent in electrical equipment, 33 per cent in chemical. That is, FDI tended to privilege those industries in which Italian entrepreneurship was weaker and in which the amount of capital needed for investment was larger and not immediately available on the domestic financial market (Colli 2010).

In the $1880 \mathrm{~s}$, the introduction of gold standard and a massive international gold loan which came with it, boosted investment in the real estate and constructions especially for the development of the capital of the newly created Kingdom of Italy, Rome (Di Martino 2012).

International portfolio investments in Italy were principally constituted by the purchase of Italy's sovereign bonds by foreign investors (Di Martino 2001). The share of Italy's public debt in foreign hands amounted to 21.2 per cent in 1861 and reached a 41.5 per cent peak in 1889 . Then it progressively decreased up to a 13.5 per cent minimum in 1906, which was followed by a new increase that led it to 20.2 in 1913 (Zamagni 1993). In addition to servicing to public debt, this money was used for the setting-up of the state's institutions and the creation of infrastructures. As to the former, the army, the navy and education made the lion's share. Military procurements provided the main business opportunities to the first private big businesses. The procurement necessities of the Navy drove in 1884 to the establishment of the first large-scale iron and steelwork in Terni. As to the latter, the bulk of the spending went to the construction of the nation's railways network. The main long-distance railway lines were laid down in the 1860 s and early 1870 s; local networks followed in the 1880s and 1890s (Schram 1997). Although the lines were privately owned until 1884, they were heavily dependent on state subsidies and even then required two massive interventions to prevent bankruptcy before the Italian rails were nationalized in 1905 (Cohen and Federico 2001).

At least until the end of the $19^{\text {th }}$ century, railways had little effect in leading the expansion of Italy's backward engineering and metallurgical industries. By contrast, the impact of railways on the construction industry was more significant: during the two main investment cycles in the railways in the 1860s and in the $1880 \mathrm{~s}$ - about one-third of value added in the construction industry was due to the demand from the Italian railways (Fenoaltea 1983).

Moreover, new roads were laid down, the telegraph and postal systems were developed in order to reach the most remote areas in the country, and in 1881 also the public telephone network entered in operation. As a result, from 1861 to 1913 the Italian railways rose from 1,829 to 17,649 km; roads from 100,000 to $148,000 \mathrm{~km}$ (not including local roads); the telegraph lines from 9,860 to 53,518 
$\mathrm{km}$; the number of post offices from 2,220 to 9,837; and telephone subscribers from zero to 89,843 (Zamagni 1993).

\section{Conclusions}

By using Granger causation analysis and a new dataset, this paper tests the Fenoaltea's thesis with regard to both the genesis of CA fluctuations and of the investment cycle over the 1861-1913 years. The econometric results suggest that the persistent deficits in the $1860 \mathrm{~s}, 1880 \mathrm{~s}$ and in the five years prior to WW1 were generated by variations in capital inflows, as in Fenoaltea, and not by the dynamics of the GDP, as in the Bonelli-Cafagna view. This paper also finds evidence in support of the Fenoaltea's thesis that these CA deficits triggered a general investment cycle which included both construction and industrial investments Hence, Italy's persistent CA deficits seem to have resulted from capital inflows that allowed investment to rise and, in turn, to boost economic growth. Capital inflows consisted of both FDI and portfolio investments. The former flew to transports, utilities and to capital- and technology- intensive industries - such as energy, electrical equipment, chemicals - in which Italian entrepreneurship was weaker. The latter were principally constituted by the purchase of Italy's sovereign bonds by foreign investors. In addition to servicing to public debt, this money was used for the setting-up of the state's institutions and the creation of infrastructures, among which the national railway network stood out. 


\section{Tables}

Table 1. Stationarity of Italy's current account to GDP ratio, real exchange rate, real total investment, real investment in machinery and equipment, real investment in construction- A summary

\begin{tabular}{|c|c|c|c|c|}
\hline Variable & $\begin{array}{l}\text { LAGS used in the } \\
\text { ADF and KPSS tests }\end{array}$ & $\begin{array}{c}\text { Degree of integration } \\
\text { from the ADF test - } \\
\text { OLS }\end{array}$ & $\begin{array}{c}\text { Degree of integration } \\
\text { from the ADF test - } \\
\text { GLS }\end{array}$ & $\begin{array}{l}\text { Degree of integration } \\
\text { from the KPSS test }\end{array}$ \\
\hline \multicolumn{5}{|l|}{$\begin{array}{c}\text { Current Account } \\
\text { /GDP }\end{array}$} \\
\hline CA/GDP & 0 & $\mathrm{I}(\mathbf{0}) / \mathrm{I}(\mathbf{1})$ & $\mathrm{I}(0)$ & $\mathrm{I}(0)$ \\
\hline CA/GDP & 1 & $\mathbf{I}(\mathbf{0}) / \mathbf{I}(\mathbf{1})$ & $\mathbf{I}(\mathbf{0}) / \mathbf{I}(\mathbf{1})$ & I(1) \\
\hline CA/GDP & 4 & I(1) & I(1) & $\mathrm{I}(0)$ \\
\hline$\Delta$ (CA/GDP) & 0 & $\mathrm{I}(0)$ & $\mathrm{I}(0)$ & $\mathrm{I}(0)$ \\
\hline$\Delta(\mathrm{CA} / \mathrm{GDP})$ & 1 & $\mathrm{I}(0)$ & $\mathrm{I}(0)$ & $\mathrm{I}(0)$ \\
\hline \multicolumn{5}{|l|}{ Real Exchange rate } \\
\hline$\varepsilon$ & 0 & $\mathrm{I}(1)$ & $\mathrm{I}(1)$ & $\mathrm{I}(1)$ \\
\hline$\varepsilon$ & 1 & $\mathrm{I}(1)$ & $\mathrm{I}(1)$ & $\mathrm{I}(1)$ \\
\hline$\varepsilon$ & 4 & $\mathrm{I}(1)$ & $\mathrm{I}(1)$ & $\mathrm{I}(1)$ \\
\hline$\Delta \varepsilon$ & 0 & $\mathrm{I}(0)$ & $\mathrm{I}(0)$ & $\mathrm{I}(0)$ \\
\hline$\Delta \varepsilon$ & 1 & $\mathrm{I}(0)$ & $\mathrm{I}(0)$ & $\mathrm{I}(0)$ \\
\hline \multicolumn{5}{|l|}{$\begin{array}{c}\text { Real total } \\
\text { investment }\end{array}$} \\
\hline real Total I & 0 & $\mathrm{I}(1)$ & $\mathrm{I}(1)$ & $\mathrm{I}(1)$ \\
\hline real Total I & 1 & $\mathrm{I}(1)$ & $\mathrm{I}(1)$ & $\mathrm{I}(1)$ \\
\hline real Total I & 4 & $\mathrm{I}(1)$ & $\mathrm{I}(1)$ & $\mathrm{I}(1)$ \\
\hline$\Delta$ real Total I & 0 & $\mathrm{I}(0)$ & $\mathrm{I}(0)$ & $\mathrm{I}(0)$ \\
\hline$\Delta$ real Total I & 1 & $\mathrm{I}(0)$ & $\mathrm{I}(0)$ & $\mathrm{I}(0)$ \\
\hline \multicolumn{5}{|l|}{$\begin{array}{l}\text { Real investment in } \\
\text { plant, machinery } \\
\text { and transport } \\
\text { equipment }\end{array}$} \\
\hline real IE & 0 & $\mathrm{I}(1)$ & $\mathrm{I}(1)$ & $\mathrm{I}(1)$ \\
\hline real IE & 1 & $\mathrm{I}(1)$ & $\mathrm{I}(1)$ & $\mathrm{I}(1)$ \\
\hline real IE & 4 & $\mathrm{I}(1)$ & $\mathrm{I}(1)$ & $\mathrm{I}(1)$ \\
\hline$\Delta$ real IE & 0 & $\mathrm{I}(0)$ & $\mathrm{I}(0)$ & $\mathrm{I}(0)$ \\
\hline$\Delta$ real IE & 1 & $\mathrm{I}(0)$ & $\mathrm{I}(0)$ & $\mathrm{I}(0)$ \\
\hline \multicolumn{5}{|l|}{$\begin{array}{l}\text { Real investment in } \\
\text { constructions }\end{array}$} \\
\hline real IC & 0 & $\mathrm{I}(1)$ & $\mathrm{I}(1)$ & $\mathrm{I}(1)$ \\
\hline real IC & 1 & $\mathrm{I}(1)$ & $\mathrm{I}(1)$ & $\mathrm{I}(1)$ \\
\hline real IC & 4 & $\mathrm{I}(1)$ & $\mathrm{I}(1)$ & $\mathrm{I}(1)$ \\
\hline$\Delta$ real IC & 0 & $\mathrm{I}(0)$ & $\mathrm{I}(0)$ & $\mathrm{I}(0)$ \\
\hline$\Delta$ real IC & 1 & $\mathrm{I}(0)$ & $\mathrm{I}(0)$ & $\mathrm{I}(0)$ \\
\hline
\end{tabular}

Notes: $\mathrm{I}(0)$ means stationary series (no unit root is present). I(1) means non stationary series (i.e presence of at least one unit root). Note these tests are available on a preliminary draft of the paper (Pistoresi and Rinaldi, 2013). For real investment construction series , the results are available on request. 
Table 2. Long run comovements (common trends) among current account to GDP ratio, real exchange rate, and real investment series (logs) - Engle and Granger cointegration analysis

\begin{tabular}{|c|c|}
\hline \multicolumn{2}{|c|}{ Engle - Granger long run regression: $\boldsymbol{C A} / \mathbf{G D P} \boldsymbol{P}_{\boldsymbol{t}}=\alpha+\beta_{1} \varepsilon+\beta_{2}$ realGDP$+\eta_{\boldsymbol{t}}$} \\
\hline Variables & $\boldsymbol{H}_{0}:$ unit root in $\eta_{t}$, no cointegration \\
\hline $\mathrm{CA} / \mathrm{GDP}, \varepsilon$ & Test $=-2.65$, p- value $=0.23$, does not reject $\boldsymbol{H}_{0}:$ NO COINTEGRATION \\
\hline $\mathrm{CA} / \mathrm{GDP}, \varepsilon$, real investment (total) & Test $=-2.77, \mathrm{p}-$ value $=0.36$, does not reject $\boldsymbol{H}_{0}:$ NO COINTEGRATION \\
\hline CA/GDP, $\varepsilon$, real IE (plant, machinery and transport equipment) & Test $=-2.86$, p- value $=0.32$, does not reject $\boldsymbol{H}_{0}:$ NO COINTEGRATION \\
\hline CA/GDP, $\varepsilon$, real investment (construction) & Test $=-3.05, \mathrm{p}$ - value $=0.25$, does not reject $\boldsymbol{H}_{0}:$ NO COINTEGRATION \\
\hline
\end{tabular}

Notes: $5 \%$ critical values fot the Engle - Granger ADF test for cointegration: -3.80 ( two regressors included) -4.16 (three regressors included) see Philips - Ouliaris (1990). P-values in Mac Kinnon (1996). The no cointegration result is also obtained Johansen cointegration procedure - Johansen (1991). 
Table 3. Current account to GDP ratio, real exchange rate and real investment in plant, machinery and transport equipment - Granger causality

\begin{tabular}{|c|c|c|c|c|}
\hline \multicolumn{5}{|c|}{$\Delta \boldsymbol{C A} / \boldsymbol{G D P} \boldsymbol{P}_{t}=\alpha+\beta_{1} \Delta(\boldsymbol{C A} / \boldsymbol{G D P})_{t-1}+\ldots+\delta_{1} \Delta \varepsilon_{t-1}+\ldots+\gamma_{1} \Delta$ realIE $t_{t-1}+\ldots+\eta_{t}$} \\
\hline & $H_{0}:$ the past does not matter & F test - p-value & Outcome & Conclusion \\
\hline $\operatorname{ADL}(1,1)$ & $\boldsymbol{H}_{0}: \gamma_{1}=0$ & p-value $=0.60$ & Fail to reject $\boldsymbol{H}_{0}$ & Changes in I growth do not cause CA/GDP \\
\hline $\operatorname{ADL}(2,2)$ & $\boldsymbol{H}_{0}: \gamma_{1}=\gamma_{2}=0$ & $\mathrm{p}$-value $=0.84$ & Fail to reject $\boldsymbol{H}_{0}$ & Changes in I growth do not cause CA/GDP \\
\hline $\operatorname{ADL}(3,3)$ & $\boldsymbol{H}_{0}: \gamma_{1}=\gamma_{2}=\gamma_{3}=0$ & $\mathrm{p}$-value $=0.62$ & Fail to reject $\boldsymbol{H}_{0}$ & Changes in I growth do not cause CA/GDP \\
\hline $\operatorname{ADL}(1,1)$ & $\boldsymbol{H}_{0}: \delta_{1}=0$ & $\mathrm{p}$-value $=0.06$ & Reject $\boldsymbol{H}_{0}(6 \%)$ & Changes in exchange rate cause $\mathrm{CA} / \mathrm{GDP}$ \\
\hline $\operatorname{ADL}(2,2)$ & $\boldsymbol{H}_{0}: \delta_{1}=\delta_{2}=0$ & p-value $=0.04$ & Reject $\boldsymbol{H}_{0}$ & Changes in exchange rate cause CA/GDP \\
\hline $\operatorname{ADL}(3,3)$ & $\boldsymbol{H}_{0}: \delta_{1}=\delta_{2}=\delta_{3}=0$ & $\mathrm{p}$-value $=0.00$ & Reject $\boldsymbol{H}_{0}$ & Changes in exchange rate cause CA/GDP \\
\hline \multicolumn{5}{|c|}{$\Delta$ LrealIE $_{t}=\alpha+\beta_{1} \Delta(\mathbf{C A} / \mathbf{G D P})_{t-1}+\ldots+\delta_{1} \Delta \varepsilon_{t-1}+\ldots+\gamma_{1} \Delta$ realIE $E_{t-1}+\ldots+\eta_{t}$} \\
\hline & $H_{0}:$ the past does not matter & F test - p-value & Outcome & Conclusion \\
\hline $\operatorname{ADL}(1,1)$ & $\boldsymbol{H}_{0}: \beta_{1}=0$ & p-value $=0.05$ & Reject $\boldsymbol{H}_{0}$ & Changes in CA/GDP cause I growth \\
\hline $\operatorname{ADL}(2,2)$ & $\boldsymbol{H}_{0}: \beta_{1}=\beta_{2}=0$ & p-value $=0.00$ & Reject $\boldsymbol{H}_{0}$ & Changes in CA/GDP cause I growth \\
\hline $\operatorname{ADL}(3,3)$ & $\boldsymbol{H}_{0}: \beta_{1}=\beta_{2}=\beta_{3}=0$ & p-value $=0.01$ & Reject $\boldsymbol{H}_{0}$ & Changes in CA/GDP cause I growth \\
\hline$\overline{\mathrm{ADL}}(1,1)$ & $\boldsymbol{H}_{0}: \delta_{1}=0$ & p-value $=0.21$ & Fail to reject $\boldsymbol{H}_{0}$ & Changes in exchange rate do not cause I growth \\
\hline $\operatorname{ADL}(2,2)$ & $\boldsymbol{H}_{0}: \delta_{1}=\delta_{2}=0$ & p-value $=0.76$ & Fail to reject $\boldsymbol{H}_{0}$ & Changes in exchange rate do not cause I growth \\
\hline $\operatorname{ADL}(3,3)$ & $\boldsymbol{H}_{0}: \delta_{1}=\delta_{2}=\delta_{3}=0$ & p-value $=0.15$ & Fail to reject $\boldsymbol{H}_{0}$ & Changes in exchange rate do not cause I growth \\
\hline
\end{tabular}

\begin{tabular}{|c|c|c|c|c|}
\hline \multicolumn{5}{|c|}{$\Delta \varepsilon_{t}=\alpha+\beta_{1} \Delta(\mathbf{C A} / \boldsymbol{G D P})_{t-1}+\ldots+\delta_{1} \Delta \varepsilon_{t-1}+\ldots+\gamma_{1} \Delta$ realIE $\boldsymbol{t}_{t-1}+\ldots+\eta_{t}$} \\
\hline & $H_{0}:$ the past does not matter & $\begin{array}{l}\text { F test }-\mathbf{p -} \\
\text { value }\end{array}$ & Outcome & Conclusion \\
\hline $\operatorname{ADL}(1,1)$ & $\boldsymbol{H}_{0}: \beta_{1}=0$ & p-value $=0.37$ & Fail to reject $\boldsymbol{H}_{0}$ & Changes in CA/GDP does not cause exchange rate \\
\hline $\operatorname{ADL}(2,2)$ & $\boldsymbol{H}_{0}: \beta_{1}=\beta_{2}=0$ & $\mathrm{p}$-value $=0.94$ & Fail to reject $\boldsymbol{H}_{0}$ & Changes in CA/GDP does not cause exchange rate \\
\hline $\operatorname{ADL}(3,3)$ & $\boldsymbol{H}_{0}: \beta_{1}=\beta_{2}=\beta_{3}=0$ & $\mathrm{p}$-value $=0.18$ & Fail to reject $\boldsymbol{H}_{0}$ & Changes in CA/GDP does not cause exchange rate \\
\hline $\operatorname{ADL}(1,1)$ & $\boldsymbol{H}_{0}: \gamma_{1}=0$ & $\mathrm{p}$-value $=0.29$ & Fail to reject $\boldsymbol{H}_{0}$ & Changes in I growth do not cause exchange rate \\
\hline $\operatorname{ADL}(2,2)$ & $\boldsymbol{H}_{0}: \gamma_{1}=\gamma_{2}=0$ & $\mathrm{p}$-value $=0.81$ & Fail to reject $\boldsymbol{H}_{0}$ & Changes in I growth do not cause exchange rate \\
\hline $\operatorname{ADL}(3,3)$ & $\boldsymbol{H}_{0}: \gamma_{1}=\gamma_{2}=\gamma_{3}=0$ & p-value $=0.41$ & Fail to reject $\boldsymbol{H}_{0}$ & Changes in I growth do not cause exchange rate \\
\hline
\end{tabular}

Notes: The no cointegration result implies we estimate an ADL models instead of an ECM models. Robust standard errors estimation. 
Table 4. Current account to GDP ratio, real exchange rate and real investment in constructions - Granger causality

\begin{tabular}{|c|c|c|c|c|}
\hline \multicolumn{5}{|c|}{$\Delta \boldsymbol{C A} / \boldsymbol{G D P} \boldsymbol{P}_{t}=\alpha+\beta_{1} \Delta(\mathbf{C A} / \mathbf{G D P})_{t-1}+\ldots+\delta_{1} \Delta \varepsilon_{t-1}+\ldots+\gamma_{1} \Delta r e a l I C_{t-1}+\ldots+\eta_{t}$} \\
\hline & $\boldsymbol{H}_{0}$ : the past does not matter & F test $-p$-value & Outcome & Conclusion \\
\hline $\operatorname{ADL}(1,1)$ & $\boldsymbol{H}_{0}: \gamma_{1}=0$ & $\mathrm{p}$-value $=0.22$ & Fail to reject $\boldsymbol{H}_{0}$ & Changes in I growth does not cause CA/GDP \\
\hline $\operatorname{ADL}(2,2)$ & $\boldsymbol{H}_{0}: \gamma_{1}=\gamma_{2}=0$ & $\mathrm{p}$-value $=0.55$ & Fail to reject $\boldsymbol{H}_{0}$ & Changes in I growth does not cause CA/GDP \\
\hline $\operatorname{ADL}(3,3)$ & $\boldsymbol{H}_{0}: \gamma_{1}=\gamma_{2}=\gamma_{3}=0$ & $\mathrm{p}$-value $=0.26$ & Fail to reject $\boldsymbol{H}_{0}$ & Changes in I growth do not cause CA/GDP \\
\hline $\operatorname{ADL}(1,1)$ & $\boldsymbol{H}_{0}: \delta_{1}=0$ & $\mathrm{p}$-value $=0.10$ & Reject $\boldsymbol{H}_{0}(10 \%)$ & Changes in exchange rate cause $\mathrm{CA} / \mathrm{GDP}$ \\
\hline $\operatorname{ADL}(2,2)$ & $\boldsymbol{H}_{0}: \delta_{1}=\delta_{2}=0$ & p-value $=0.03$ & Reject $\boldsymbol{H}_{0}$ & Changes in exchange rate cause CA/GDP \\
\hline $\operatorname{ADL}(3,3)$ & $\boldsymbol{H}_{0}: \delta_{1}=\delta_{2}=\delta_{3}=0$ & $\mathrm{p}$-value $=0.001$ & Reject $\boldsymbol{H}_{0}$ & Changes in exchange rate cause CA/GDP \\
\hline \multicolumn{5}{|c|}{$\Delta$ LrealIC $_{t}=\alpha+\beta_{1} \Delta(\mathbf{C A} / \mathbf{G D P})_{t-1}+\ldots+\delta_{1} \Delta \varepsilon_{t-1}+\ldots+\gamma_{1} \Delta r e a l I C_{t-1}+\ldots+\eta_{t}$} \\
\hline & & F test - p-value & Outcome & Conclusion \\
\hline $\operatorname{ADL}(1,1)$ & $\boldsymbol{H}_{0}: \beta_{1}=0$ & $\mathrm{p}$-value $=0.42$ & Fail to reject $\boldsymbol{H}_{0}$ & Changes in CA/GDP does not cause I growth \\
\hline $\operatorname{ADL}(2,2)$ & $\boldsymbol{H}_{0}: \beta_{1}=\beta_{2}=0$ & $\mathrm{p}$-value $=0.16$ & Fail to reject $\boldsymbol{H}_{0}$ & Changes in CA/GDP does not cause I growth \\
\hline $\operatorname{ADL}(3,3)$ & $\boldsymbol{H}_{0}: \beta_{1}=\beta_{2}=\beta_{3}=0$ & p-value $=0.012$ & Reject $\boldsymbol{H}_{0}$ & Changes in CA/GDP cause I growth \\
\hline $\operatorname{ADL}(1,1)$ & $\boldsymbol{H}_{0}: \delta_{1}=0$ & $\mathrm{p}$-value $=0.07$ & Fail to reject $\boldsymbol{H}_{0}$ & Changes in exchange rate does not cause I growth \\
\hline $\operatorname{ADL}(2,2)$ & $\boldsymbol{H}_{0}: \delta_{1}=\delta_{2}=0$ & p-value $=0.43$ & Fail to reject $\boldsymbol{H}_{0}$ & Changes in exchange rate does not cause I growth \\
\hline$\overline{\operatorname{ADL}(3,3)}$ & $\boldsymbol{H}_{0}: \delta_{1}=\delta_{2}=\delta_{3}=0$ & $\mathrm{p}$-value $=0.15$ & Fail to reject $\boldsymbol{H}_{0}$ & Changes in exchange rate does not cause I growth \\
\hline
\end{tabular}

\begin{tabular}{|c|c|c|c|c|}
\hline \multicolumn{5}{|c|}{$\Delta \varepsilon_{t}=\alpha+\beta_{1} \Delta(\mathbf{C A} / \mathbf{G D P})_{t-1}+\ldots+\delta_{1} \Delta \varepsilon_{t-1}+\ldots+\gamma_{1} \Delta r e a l I C_{t-1}+\ldots+\eta_{t}$} \\
\hline & $H_{0}:$ the past does not matter & $\begin{array}{l}\text { F test }-\mathbf{p}^{-} \\
\text {value }\end{array}$ & Outcome & Conclusion \\
\hline $\operatorname{ADL}(1,1)$ & $\boldsymbol{H}_{0}: \beta_{1}=0$ & $\mathrm{p}$-value $=0.76$ & Fail to reject $\boldsymbol{H}_{0}$ & Changes in CA/GDP does not cause exchange rate \\
\hline $\operatorname{ADL}(2,2)$ & $\boldsymbol{H}_{0}: \beta_{1}=\beta_{2}=0$ & p-value $=0.93$ & Fail to reject $\boldsymbol{H}_{0}$ & Changes in CA/GDP does not cause exchange rate \\
\hline $\operatorname{ADL}(3,3)$ & $\boldsymbol{H}_{0}: \beta_{1}=\beta_{2}=\beta_{3}=0$ & $\mathrm{p}$-value $=0.11$ & Reject $\boldsymbol{H}_{0}$ & Changes in CA/GDP does not cause exchange rate \\
\hline $\operatorname{ADL}(1,1)$ & $\boldsymbol{H}_{0}: \gamma_{1}=0$ & $\mathrm{p}$-value $=0.19$ & Fail to reject $\boldsymbol{H}_{0}$ & Changes in I growth does not cause exchange rate \\
\hline $\operatorname{ADL}(2,2)$ & $\boldsymbol{H}_{0}: \gamma_{1}=\gamma_{2}=0$ & $\mathrm{p}$-value $=0.31$ & Fail to reject $\boldsymbol{H}_{0}$ & Changes in I growth does not cause exchange rate \\
\hline $\operatorname{ADL}(3,3)$ & $\boldsymbol{H}_{0}: \gamma_{1}=\gamma_{2}=\gamma_{3}=0$ & $\mathrm{p}$-value $=0.38$ & Fail to reject $\boldsymbol{H}_{0}$ & Changes in I growth does not cause exchange rate \\
\hline
\end{tabular}

Notes: The no cointegration result implies we estimate ADL models instead of an ECM models. Robust standard errors estimation. 
Table 5. Current account to GDP ratio, real exchange rate and real total investments Granger causality

\begin{tabular}{|c|c|c|c|c|}
\hline \multicolumn{5}{|c|}{$\Delta \boldsymbol{C A} / \boldsymbol{G D P} \boldsymbol{P}_{t}=\alpha+\beta_{1} \Delta(\mathbf{C A} / \boldsymbol{G D P})_{t-1}+\ldots+\delta_{1} \Delta \varepsilon_{t-1}+\ldots+\gamma_{1} \Delta r e a l I_{t-1}+\ldots+\eta_{t}$} \\
\hline & $H_{0}:$ the past does not matter & $\begin{array}{l}\text { F test }-p- \\
\text { value }\end{array}$ & Outcome & Conclusion \\
\hline $\operatorname{ADL}(1,1)$ & $\boldsymbol{H}_{0}: \gamma_{1}=0$ & p-value $=0.04$ & Reject $\boldsymbol{H}_{0}$ & Changes in I growth cause CA/GDP variations \\
\hline $\operatorname{ADL}(2,2)$ & $\boldsymbol{H}_{0}: \gamma_{1}=\gamma_{2}=0$ & $\mathrm{p}$-value $=0.23$ & Fail to reject $\boldsymbol{H}_{0}$ & Changes in I growth do not cause CA/GDP variations \\
\hline $\operatorname{ADL}(3,3)$ & $\boldsymbol{H}_{0}: \gamma_{1}=\gamma_{2}=\gamma_{3}=0$ & $\mathrm{p}$-value $=0.33$ & Fail to reject $\boldsymbol{H}_{0}$ & Changes in I growth do not cause CA/GDP variations \\
\hline $\operatorname{ADL}(1,1)$ & $\boldsymbol{H}_{0}: \delta_{1}=0$ & $\mathrm{p}$-value $=0.10$ & Reject $\boldsymbol{H}_{0}(10 \%)$ & Changes in exchange rate cause CA/GDP variations \\
\hline $\operatorname{ADL}(2,2)$ & $\boldsymbol{H}_{0}: \delta_{1}=\delta_{2}=0$ & $\mathrm{p}$-value $=0.05$ & Reject $\boldsymbol{H}_{0}$ & Changes in exchange rate cause CA/GDP variations \\
\hline $\operatorname{ADL}(3,3)$ & $\boldsymbol{H}_{0}: \delta_{1}=\delta_{2}=\delta_{3}=0$ & $\mathrm{p}$-value $=0.01$ & Reject $\boldsymbol{H}_{0}$ & Changes in exchange rate cause CA/GDP variations \\
\hline \multicolumn{5}{|c|}{$\Delta$ LrealI $_{t}=\alpha+\beta_{1} \Delta(\mathbf{C A} / \mathbf{G D P})_{t-1}+\ldots+\delta_{1} \Delta \varepsilon_{t-1}+\ldots+\gamma_{1} \Delta$ realI $t_{t-1}+\ldots+\eta_{t}$} \\
\hline & $H_{0}$ : the past does not matter & $\begin{array}{l}\text { F test }-p- \\
\text { value }\end{array}$ & Outcome & Conclusion \\
\hline $\operatorname{ADL}(1,1)$ & $\boldsymbol{H}_{0}: \beta_{1}=0$ & $\mathrm{p}$-value $=0.15$ & Fail to reject $\boldsymbol{H}_{0}$ & Changes in CA/GDP do not cause I growth \\
\hline $\operatorname{ADL}(2,2)$ & $\boldsymbol{H}_{0}: \beta_{1}=\beta_{2}=0$ & $\mathrm{p}$-value $=0.06$ & Reject $\boldsymbol{H}_{0}(6 \%)$ & Changes in CA/GDP cause I growth \\
\hline $\operatorname{ADL}(3,3)$ & $\boldsymbol{H}_{0}: \beta_{1}=\beta_{2}=\beta_{3}=0$ & $\mathrm{p}$-value $=0.16$ & Reject $\boldsymbol{H}_{0}$ & Changes in CA/GDP do not cause I growth \\
\hline $\operatorname{ADL}(1,1)$ & $\boldsymbol{H}_{0}: \delta_{1}=0$ & $\mathrm{p}$-value $=0.20$ & Fail to reject $\boldsymbol{H}_{0}$ & Changes in exchange rate do not cause I growth \\
\hline $\operatorname{ADL}(2,2)$ & $\boldsymbol{H}_{0}: \delta_{1}=\delta_{2}=0$ & $\mathrm{p}$-value $=0.07$ & Reject $\boldsymbol{H}_{0}(7 \%)$ & Changes in exchange rate cause I growth \\
\hline $\operatorname{ADL}(3,3)$ & $\boldsymbol{H}_{0}: \delta_{1}=\delta_{2}=\delta_{3}=0$ & $\mathrm{p}$-value $=0.02$ & Reject $\boldsymbol{H}_{0}$ & Changes in exchange rate cause I growth \\
\hline
\end{tabular}

\begin{tabular}{|c|c|c|c|c|}
\hline \multicolumn{5}{|c|}{$\Delta \varepsilon_{t}=\alpha+\beta_{1} \Delta(\mathbf{C A} / \mathbf{G D P})_{t-1}+\ldots+\delta_{1} \Delta \varepsilon_{t-1}+\ldots+\gamma_{1} \Delta$ realI $t_{t-1}+\ldots+\eta_{t}$} \\
\hline & $\begin{array}{l}H_{0}: \text { the past of the current } \\
\text { account does not matter }\end{array}$ & $\begin{array}{l}\text { F test }-p- \\
\text { value }\end{array}$ & Outcome & Causality Conclusion \\
\hline $\operatorname{ADL}(1,1)$ & $\boldsymbol{H}_{0}: \beta_{1}=0$ & $\mathrm{p}$-value $=0.72$ & Fail to reject $\boldsymbol{H}_{0}$ & Changes in CA/GDP does not cause exchange rate \\
\hline $\operatorname{ADL}(2,2)$ & $\boldsymbol{H}_{0}: \beta_{1}=\beta_{2}=0$ & $\mathrm{p}$-value $=0.96$ & Fail to reject $\boldsymbol{H}_{0}$ & Changes in CA/GDP does not cause exchange rate \\
\hline $\operatorname{ADL}(3,3)$ & $\boldsymbol{H}_{0}: \beta_{1}=\beta_{2}=\beta_{3}=0$ & p-value $=0.19$ & Fail to reject $\boldsymbol{H}_{0}$ & Changes in CA/GDP does not cause exchange rate \\
\hline $\operatorname{ADL}(1,1)$ & $\boldsymbol{H}_{0}: \gamma_{1}=0$ & p-value $=0.34$ & Fail to reject $\boldsymbol{H}_{0}$ & Changes in I growth do not cause exchange rate \\
\hline $\operatorname{ADL}(2,2)$ & $\boldsymbol{H}_{0}: \gamma_{1}=\gamma_{2}=0$ & $\mathrm{p}$-value $=0.52$ & Fail to reject $\boldsymbol{H}_{0}$ & Changes in I growth do not cause exchange rate \\
\hline $\operatorname{ADL}(3,3)$ & $\boldsymbol{H}_{0}: \gamma_{1}=\gamma_{2}=\gamma_{3}=0$ & $\mathrm{p}$-value $=0.55$ & Fail to reject $\boldsymbol{H}_{0}$ & Changes in I growth do not cause exchange rate \\
\hline
\end{tabular}

Notes: The no cointegration result implies we estimate an ADL models instead of an ECM models. Robust standard errors estimation. 


\section{BIBLIOGRAPHY}

BAFFIGI, Alberto (2011), "Italian National Accounts, 1861-2011", Quaderni di Storia Economica (Economic History Working Papers) No. 18, Banca d'Italia, Rome.

BOLCHINI, Piero, CIOCCA, Pierluigi, DE CECCO, Marcello, FEDERICO, Giovanni, TATTARA, Giuseppe, TONIOLO, Gianni, and ZAMAGNI, Vera (2006), “A proposito di Stefano Fenoaltea, L'economia italiana dall'Unità nazionale alla Grande Guerra, Bari-Roma, 2006”, Rivista di storia economica, Nuova serie, 22, pp. 331-375.

BONELLI, Franco (1978), "Il capitalismo italiano: linee generali di interpretazione”, in Ruggero ROMANO and Corrado VIVANTI (eds), Storia d'Italia. Annali I. Dal feudalesimo al capitalismo, Einaudi, Turin, pp. 1193-1255.

BRUNETTI, Alessandro, FELICE, Emanuele, and VECCHI, Giovanni (2011), "Reddito", in Giovanni VECCHI (ed.), In ricchezza e in povertà. Il benessere degli italiani dall’Unità a oggi, Il Mulino, Bologna, pp. 209-234.

CAFAGNA, Luciano (1989), Dualismo e sviluppo nella storia d'Italia, Marsilio, Venice.

COHEN, Jon, and FEDERICO, Giovanni (2001), The Growth of the Italian Economy 1820-1960, Cambridge University Press, Cambridge.

COLLI, Andrea (2010), "Foreign enterprises (1913-72)", in Andrea COLLI and Michelangelo VASTA (eds), Forms of enterprise in $20^{\text {th }}$ century Italy. Boundaries, Structures and Strategies, Elgar, Cheltenham-Northampton, MA, pp. $87-$ 111.

DICKEY David A., and FULLER Wayne A. (1979), "Distribution of the estimators for autoregressive time series with a unit root", Journal of the American Statistical Association, 74(366), pp. 427-431.

DI MARTINO, Paolo (2001), “Corso della Rendita e andamenti del tasso di cambio della Lira negli anni del gold standard (1883-1993)", Rivista di storia economica, n.s., 17 (1), pp. 3-31.

DI MARTINO, Paolo (2012), “'Rome wasn't built in a day': lobbies, institutions and speculation in the 1880s fever”, Urban History, 39 (03), pp. 471-89.

ERCOLANI, Paolo (1969), "Documentazione statistica di base”, in Giorgio FUÀ (ed.), Lo sviluppo economico in Italia, vol. 3, Franco Angeli, Milan.

FENOALTEA, Stefano (1983), “Italy”, in Patrick K. O’ BRIEN (ed.), Railways and the Economic Development of Western Europe, Macmillan, London, pp. 49-120.

FENOALTEA, Stefano (1988), "International resource flows and construction movements in the Atlantic economy: the Kuznets cycle in Italy", Journal of Economic History, 48, pp. 605-37

FENOALTEA, Stefano (2011), The Reinterpretation of Italian Economic History: From Unification to the Great War, Cambridge University Press, Cambridge.

FRATIANNI, M., and SPINELLI, F. (1984), "Italy in the gold standard period 1861-1914", in Michael BORDO and Anna J. SCHWARTZ (eds), A retrospective on the classical gold standard 1821-1931 (Chicago), pp. 404-38.

FUÀ, Giorgio (1965), Notes on Italian Economic Growth 1861-1964, Giuffrè, Milan.

FUÀ, Giorgio (1969), Lo sviluppo economico in Italia, 3 vols, Franco Angeli, Milan.

GRANGER, Clive W.J. (1969), "Investigating causal relations by econometric models: cross spectral methods", Econometrica, 37, pp. 424-438.

GRANGER, Clive W.J. (1988), "Some recent developments in the concept of causality", Journal of Econometrics, 39, pp. 199-211.

ISTAT (1957), "Indagine statistica sullo sviluppo del reddito nazionale dell'Italia dal 1861 al 1956", Annali di statistica, serie VIII, vol. 9, Istat, Rome. 
JOHANSEN, Soren (1991), "Estimation and hypothesis test of cointegrating vectors in Gaussian vector autoregressive models", Econometrica, 59, pp. 1551-1580.

KWIATKOWSKI, Denis, PHILLIPS, Peter C.B., SCHMIDT, Peter, and SHIN Yongcheol (1992), "Testing the null hypothesis of stationarity against the alternative of a unit root", Journal of Econometrics, vol. 54, 159-178.

MAROLLA, Mauro, and ROCCAS, Massimo (1992), "La ricostruzione delle bilancia internazionale dei servizi e trasferimenti unilaterali dell'anno 1911", in Guido M. REY (ed), I conti economici dell'Italia. 2. Una stima del valore aggiunto per il 1911, vol. I.II., Laterza, Rome-Bari, pp. 241-282.

MORYS, Ingo M. (2006), "The Classical Gold Standard in the European Periphery: A case Study of Austria-Hungary and Italy, 1870-1913”, PhD thesis, London School of Economics and Political Science.

PISTORESI, Barbara, and RINALDI, Alberto (2013), "External constraint and economic growth in Italy: 1861-2000", DEMB Working papers Series No. 11, Dipartimento di Economia "Marco Biagi”, Modena.

PRADOS DE LA ESCOSURA, Leandro (2010), “Spain's International position, 1850-1913”, Revista de Historia Económica, 28, pp.173-215.

SCHRAM, A. (1997), Railways and the formation of the Italian state in the nineteenth century, Cambridge University Press, Cambridge.

SPINELLI, F. (1988), "Pasquale Jannacone: a neglected originator of the monetary approach to balance of payments and exchange rates”, Journal of European Economic History, 17, pp. 203-25.

STOCK, James H, and WATSON Mark W. (1993), “A simple estimator of cointegration vectors in higher-order integrated systems”, Econometrica, 61(4), pp. 783-820.

VITALI, Ornello (1969), "La stima del valore aggiunto a prezzi costanti per rami di attività", in Giorgio FUÀ (ed.), Lo sviluppo economico in Italia, vol. 3, Franco Angeli, Milan.

WARGLIEN, Massimo (1987), "Investimenti industriali ed instabilità finanziaria in Italia”, Rivista di storia economica, n.s., 3, pp. 384-439.

ZAMAGNI, Vera (1978), Industrializzazione e squilibri regionali in Italia, Il Mulino, Bologna.

ZAMAGNI, Vera (1992), "Il valore aggiunto del settore terziario italiano nel 1911”, in Guido M. REY (ed.), I conti economici dell'Italia. 2. Una stima del valore aggiunto per il 1911, vol. I.II., Laterza, Rome-Bari, pp. 191-239.

ZAMAGNI, Vera (1993), The Economic History of Italy 1860-1990. Recovery after Decline, Clarendon Press, Oxford. 